\title{
Inflammation, Cytokines, Immune Response, Apolipoprotein E, Cholesterol, and Oxidative Stress in Alzheimer Disease: Therapeutic Implications
}

\author{
Giuseppina Candore, ${ }^{1}$ Matteo Bulati, ${ }^{1}$ Calogero Caruso, ${ }^{1}$ Laura Castiglia, ${ }^{1}$ Giuseppina Colonna-Romano, \\ Danilo Di Bona, ${ }^{1}$ Giovanni Duro, ${ }^{2}$ Domenico Lio,, Domenica Matranga, ${ }^{3}$ Mariavaleria Pellicanò, \\ Claudia Rizzo, ${ }^{1}$ Giovanni Scapagnini, ${ }^{4}$ and Sonya Vasto ${ }^{1}$
}

\begin{abstract}
Alzheimer disease (AD) is a heterogeneous and progressive neurodegenerative disease, which in Western society mainly accounts for senile dementia. Today many countries have rising aging populations and are facing an increased prevalence of age-related diseases, such as $\mathrm{AD}$, with increasing health-care costs. Understanding the pathophysiology process of $\mathrm{AD}$ plays a prominent role in new strategies for extending the health of the elderly population. Considering the future epidemic of $\mathrm{AD}$, prevention and treatment are important goals of ongoing research. However, a better understanding of AD pathophysiology must be accomplished to make this objective feasible. In this paper, we review some hot topics concerning AD pathophysiology that have an important impact on therapeutic perspectives. Hence, we have focused our attention on inflammation, cytokines, immune response, apolipoprotein E (APOE), cholesterol, oxidative stress, as welll as exploring the related therapeutic possibilities, i.e., nonsteroidal antiinflammatory drugs, cytokine blocking antibodies, immunotherapy, diet, and curcumin.
\end{abstract}

\section{Introduction}

$\mathbf{T}$ HE MOST COMMON FORM OF DEMENTIA, Alzheimer disease (AD) is a progressive neurodegenerative illness that affects nearly $0.6 \%$ of those persons aged $65-69,1.0 \%$ of ages $70-74,2.0 \%$ of ages $75-79,3.3 \%$ of ages $80-84$, and $8.4 \%$ of persons 85 and older. Thus, it represents a growing public health problem as life expectancy increases. AD is characterized by progressive memory deficits, cognitive impairment, and personality changes with behavioral and emotional disturbances that may eventually interfere with the patient's ability to perform the basic activities of daily living. These symptoms are a result of neuronal death, especially in the limbic and association cortices, which have roles in memory and navigation. ${ }^{1-3}$ Neuronal death follows a period of progressive synaptic dysfunction caused by the senile plaques, characterized by the accumulation of proteins in the form of $\beta$-pleated sheet fibrils, which are composed mainly of a 42 -amino-acid peptide known as $\beta$-amyloid $(\mathrm{A} \beta)$, and neurofibrillary tangles, mainly composed by a cyto- skeletal hyperphosphorylated protein tau. The relative contributions of $\mathrm{A} \beta$ and tau to the process of neuronal death is the subject of intense debate in the field. However, the "amyloid cascade hypothesis" supports the idea that $\mathrm{A} \beta$ is the main pathogenetic factor of $\mathrm{AD}$ due to the aberrant metabolism of the amyloid precursor protein. The subsequent massive production and deposition of the peptide in extracellular sites are responsible for a concatenate series of events that result in neurotoxicity and consequent neuronal death. Many inflammatory mediators have been detected in several regions of the brain of $\mathrm{AD}$ patients and in astrocyte and microglial cells activation, which have a fundamental role in the inflammatory pathogenesis, as stated by the amyloid cascade/neuroinflammation hypothesis. ${ }^{4-6}$

Events contributing to AD development are numerous and complex. The pathogenesis involves a multitude of variables, many of which remain to be quantified. Recent work highlighting the importance of immune-inflammatory responses in $\mathrm{AD}$ has led to the prospect of exciting future therapeutic options. A better understanding of the interplay

\footnotetext{
${ }^{1}$ Immunosenescence Unit, Department of Pathobiology and Biomedical Methodologies, University of Palermo, Palermo, Italy.

${ }^{2}$ IBIM, National Research Council, Palermo, Italy.

${ }^{3}$ Dipartimento di Biotecnologie Mediche e Medicina Legale, University of Palermo, Palermo, Italy.

${ }^{4}$ Department of Health Sciences, University of Molise, Campobasso, Italy.
} 
among inflammatory mediators, oxidative stress, and acquired immunity is necessary. Several inflammatory factors influencing $\mathrm{AD}$ development, i.e., environmental factors (proinflammatory phenotype) and/or genetic factors (proinflammatory genotype), have been described. ${ }^{4-11}$

Taking into account the future epidemic of $\mathrm{AD}$, prevention and treatment are important goals of ongoing research. Furthermore, a better understanding of AD pathophysiology must be accomplished to make this objective feasible. In the present paper, we will review some hot topics concerning $\mathrm{AD}$ pathophysiology and their subsequent relationship to therapeutic perspectives.

\section{Inflammation and Antiinflammatory Drugs}

Inflammation clearly occurs in pathologically vulnerable regions of the $\mathrm{AD}$ brain with the same characteristics of peripheral inflammatory responses. In the periphery, the presence of degenerating tissue and the deposition of highly insoluble abnormal materials are classical stimulants of inflammation. Likewise, in the $\mathrm{AD}$ brain, the occurrence of damaged neurons, neuritis, the deposition of highly insoluble $\mathrm{A} \beta 42$ peptide and neurofibrillary tangles provide obvious stimuli for inflammation. Moreover, senile plaques in $\mathrm{AD}$ brains are associated with reactive astrocytes and activated microglial cells, which overexpress cytokines and acute-phase proteins. ${ }^{4,12,13}$

The microglial activation can be due to local or systemic inflammation. In fact, a strong local inflammatory stimulus such as a previous head trauma is a risk factor for AD, and several epidemiological studies clearly show that blood elevations of acute-phase proteins, which are markers of systemic inflammatory stimuli, may be risk factors for cognitive decline and dementia. Furthermore, in experimental animals, chronic systemic inflammatory response induced by lipopolysaccharide administration also induces glial activation. ${ }^{14-16}$ A systemic inflammatory challenge in an animal with a chronic neurodegenerative disease leads to a significant increase in acute neurodegeneration, because microglia in the diseased or aged brain are "primed" and they switch their phenotype to produce neurotoxic molecules when they respond to systemic inflammatory signals. It has been suggested that in the diseased or aging brain, signals from systemic inflammation do not evoke a protective homeostatic response in the host, but evoke an exaggerated response that contributes to disease progression. In a retrospective general practitioner database study, the presence of two or more infections over a 4-year follow-up period was shown to increase the odds of developing AD by around two-fold. Direct evidence in humans that systemic inflammatory events might affect $\mathrm{AD}$ was shown in a 2-month study of AD patients, in which systemic infections and raised plasma levels of interleukin-1 $\beta$ (IL-1 $\beta$ ) are both associated with an increased rate of cognitive decline. ${ }^{17,18}$

Periodontal disease (PD) can be used to establish further evidence between inflammation and AD. PD is a model of chronic inflammatory disease able to influence the general status of health and the respective quality of aging. PDs are a heterogeneous group of diseases that affect the supporting structures of the teeth (gingiva, root cement, alveolar bone, and periodontal ligament). In a generic way, it is possible distinguish gingivitis as the early stage not involving tooth attachment and showing an irritation of the gums from the periodontitis that affects all of the tissues around the tooth up to the final solution of the unhappy dental loss. The etiology is complex, clinical manifestations differ, and several classifications have been proposed. The chronic stimulation of inflammation sustained by Gram-negative anaerobic bacteria of dental plaque has been correlated with various systemic diseases, such as preterm and low birth weight, atherosclerosis and cardiovascular diseases, worsening diabetes control, poor wound healing, aspiration pneumonia, and osteoporosis. ${ }^{19-21}$

At present, PD is accredited as a complex model, in which direct and indirect dynamics as well as innate, endogenous, and exogenous factors are involved. In fact, local acquired immunity reacts, producing inflammatory mediators that are able to alter vessel permeability and allowing monocytes to penetrate in the inflamed tissue. The chronic stimulation of inflammation by bacterial plaque involves several cell populations and several networks of cytokines, allowing the loss of attachment and the bone defects formation, because they amplify the inflammatory reaction and activate the effectors mechanism responsible for tissue destruction. At the same time, bacteria directly or by means of their lipopolysaccharides could reach the blood circle. $^{21,22}$

New links have been hypothesized, on the basis of the same model, for renal diseases, obesity dismetabolic syndrome, and pancreatic cancer; the most interesting link suggested is that with $\mathrm{AD} .^{21}$ It is important to emphasize that among periodontal bacteria, some species are capable of invading the brain, changing the cytokine milieu and possibly contributing to existing pathological mechanisms. ${ }^{23}$ However, it is likely that the relationship depends on the systemic inflammation.

This mechanism implies that PD-derived inflammatory molecules increase brain inflammation. The interaction between periodontal bacteria and host response results in locally increased production of inflammatory molecules. The host response to subgingival periodontal pathogens engages both innate and instructive immune responses, resulting in the alteration of local vasculature, generation of an inflammatory response, immune cell priming, and the secretion of inflammatory mediators. In periodontal health, bacteria and host response are in balance. In gingivitis, the bacterial challenge elicits an innate immune response in the adjacent gingival tissue that is able to limit bacterial-induced pathology. In periodontitis, the balance between bacteria and host response is disrupted, resulting in increased inflammatory infiltrate and the production of inflammatory mediators. Tissue destruction occurs mainly by activation of osteoclasts, matrix metalloproteinases, and other proteinases by the host inflammatory response. In severe PD, these proinflammatory molecules may induce systemic inflammation and therefore may access the brain via the systemic circulation. Proinflammatory molecules derived locally from periodontal tissue may stimulate trigeminal nerve fibers, leading to increased brain cytokines. These cytokines may act on the already primed glial cells, resulting in an amplified reaction and possible progression of $\mathrm{AD}$. A test of this hypothesis would entail examining whether PD affects the progression of AD manifested clinically as earlier onset or as more severe disease. $^{21,24}$ 
In this context, both cross-sectional and longitudinal studies have shown that patients with dementia are more likely to have poor oral health. For example, the Nun Study, a longitudinal study of aging and $\mathrm{AD}$, has offered an opportunity for studying oral health and cognitive function. Study authors found that a low number of teeth increases the risk of a higher prevalence and incidence of dementia, even in patients without the apolipoprotein-E4 (APOE4) allele (see below), although without conclusive evidence around the casual role played by each other. ${ }^{21,25-27}$ In conclusion, evidence-based data regarding the association of PD with neurodegenerative disorders are still lacking; however, it seems plausible that via contribution to systemic/brain inflammation, brain cytokines increase and activate the neurodegenerative pathway.

The role of local and systemic inflammation raises the possibility that some proinflammatory cytokine-blocking antibodies or soluble receptors could also be beneficial for preventing or treating AD (see below). Moreover, there are other less potent well-known inflammation-modulating drugs, such as statins and nonsteroidal antiinflammatory drugs (NSAIDs) that have few side effects and can be used with safety, even in very old subjects. On this basis, it is reasonable to assume that antiinflammatory treatments could be useful to counteract and to reduce both the age-dependent and the AD-dependent inflammatory status, either preventing or treating the development of AD. In particular, several epidemiological studies have suggested that longterm treatment with NSAIDs may reduce the risk of developing $\mathrm{AD}^{28-31}$ (for statins, see below). On the other hand, a recent report based on a longitudinal study of men and women aged 70 years and older with a family history of AD (ADAPT Study) showed that the use of naproxen or celecoxib did not improve cognitive function. ${ }^{32}$ However, several critical issues have been raised concerning these study results; i.e., it has been claimed that the ADAPT Study does not indicate that NSAIDs, if taken during adulthood and for an extended period, cannot prevent or delay the onset of dementia. ${ }^{33}$ In addition, examining the effects on AD risk of NSAID use for $>5$ years in a large health-care database including 49,349 cases and 196,850 controls, it has been clearly demonstrated that long-term NSAID use was protective against AD. They found that long-term users of NSAIDs were at lower-than-expected risk of AD. They found that the protective effect did not seem to be identical for each NSAID: Some showed clear protective effects, others did not, and in others the effect on AD risk was unclear. Findings were clearest for ibuprofen. A $\beta 42$-suppressing NSAIDs did not differ from others, suggesting a key role for cyclooxygenase inhibition. $^{34}$

\section{Cytokines and Anticytokines Therapy}

As reviewed recently, cytokines are critical in the pathophysiology of AD. Although evidence for cellular and humoral immunity is not present in the AD brains of individuals, cytokines including tumor necrosis factor- $\alpha$ (TNF- $\alpha$ and IL-1, as well as other components of the immune response, such as members of the complement cascade, are present. ${ }^{35,36}$ Accordingly, cytokine gene polymorphisms have been claimed to play a key role in the pathophysiology of AD. Many genetic studies have re- ported significant associations between different polymorphisms of pro- and antiinflammatory cytokines and AD. However, there are controversial findings from other studies that have not replicated the initial results. ${ }^{4}$ Metaanalysis provides a means to quantitatively synthesize association data across studies of the same genetic variant. The use of the meta-analyses has recently become an important part of genetic research, mainly to reconcile previously conducted studies that gave inconsistent results. Hence, two recent meta-analyses performed by our group on IL- $1 \beta$ and TNF- $\alpha$ clearly demonstrate the association between some functional single-nucleotide polymorphisms (SNPs) and AD. ${ }^{37,38}$

In this paper, we present data on a meta-analysis focused on transforming growth factor- $\beta$ (TGF- $\beta$ ) expressed in the brain and implicated in the pathophysiology of AD. TGF- $\beta$ might have dual proinflammatory and antiinflammatory roles, although the precise effects of TGF- $\beta$ in AD are not well understood. ${ }^{3,35}$ However, characterization of the roles of TGF- $\beta$ in AD has been addressed in experimental models of the disease. In transgenic AD-prone mice, overexpression of TGF- $\beta$ reduced plaque burden. Activation of TGF- $\beta$ in microglial cells might lead therefore to increased degradation of $\mathrm{A} \beta{ }^{39}$ Polymorphisms in the genes regulating the expression of TGF- $\beta 1$ have been hypothesized to enhance the risk of developing AD. In particular, the most studied polymorphism of TGF- $\beta$, the C/T SNP at the position 509 in the 5 -flanking region of TGF- $\beta 1$ gene, was shown to be associated with increased expression and also with increased plasma level of TGF- $\beta .^{40,41}$ However, genetic association studies investigating the association with this SNP and the risk of AD gave very contrasting results. The main causes explaining the lack of replicability of the results between different studies seems to be the heterogeneity of the enrolled study populations and the small sample size of most studies, leading to a loss of statistical power. To overcome some of the limitations mentioned above and to increase the relevance of statistical analysis, a meta-analysis of all available case-control studies on the association between TGF- $\beta 1$ SNPs and the risk of AD has been performed (Di Bona et al., unpublished observations).

The primary sources of the studies were the AlzGene database (www.alzgene.org), updated September, 2009, and the PubMed database. The medical subject headings were "TGF- $\beta 1$," "polymorphisms," and "Alzheimer's dis-

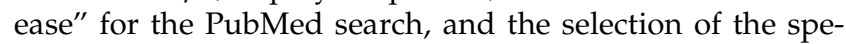
cific polymorphism (TGF- $\beta-509$; TGF- $\beta-800$; TGF- $\beta+10$; TGF- $\beta+25$ ) for the search on the AlzGene database. Data for TGF- $\beta+25$ SNPs were not extensively analyzed by meta-analysis, because less than four homogeneous samples were available. ${ }^{42-44}$ Criteria for the inclusion in the analysis were: Diagnosis of AD according to the Diagnostic and Statistical Manual of Mental Disorders (DSM), and the National Institute of Neurological Disorders and Stroke-Alzheimer Diseases and Related Disorders (NINDSADRDA) working group criteria, ${ }^{45}$ case-control studies, and available genotype. Analysis was performed as previously described, ${ }^{37,38,46}$ and the $95 \%$ confidence interval (95\% CI) of the odds ratio (OR) was also calculated. The putative risk genotype in homozygosity was compared to the other two aggregated genotypes data, condensing the results into one statistic. ${ }^{37,38}$ 
TGF- $\beta-509$ SNP

Six case-control studies on the association between TGF- $\beta$ -509 SNP and AD were identified. ${ }^{41,42,47-49}$ The effect of the TGF- $\beta-509$ TT genotype on the risk of AD is shown in the Table 1 . The effect of the TT genotype seems to increase the AD risk in two ${ }^{41,48}$ out of six studies, but a statistically significant difference was observed only in one. ${ }^{41}$ The studypooled summary OR was 1.00 (TT vs. $\mathrm{CT}+\mathrm{CC}, \mathrm{OR}=1.00$; $95 \%$ CI, 0.78-1.28), suggesting that TT subjects as high TGF- $\beta$ producers do not have a higher risk of developing AD. There was evidence of heterogeneity between the results of individual studies $\left(\chi^{2}=9.42\right.$, degrees of freedom $[\mathrm{df}]=5$, $\mathrm{p}=0.09, I^{2}=46.9 \%$ ).

TGF- $\beta+10$ SNP

Four case-control studies on the association between TGF- $\beta+10$ SNP and AD were identified. ${ }^{43,44,48,50}$ The effect of the TGF- $\beta+10$ CC genotype on the risk of AD is shown in the Table 1 . The effect of the CC genotype seems to increase the AD risk in two out of four studies, but a statistically significant difference was not observed in any study. ${ }^{43,48}$ The pooled summary OR was 0.98 (CC vs. $\mathrm{CT}+\mathrm{TT}, \mathrm{OR}=0.98 ; 95 \% \mathrm{CI}, 0.61-1.57)$, suggesting that subjects with the TGF- $\beta+10$ CC genotype do not have a higher risk of developing AD. Nor did we observe any difference in disease risk when the TT genotype was compared with the other two aggregated genotypes $(\mathrm{CT}+\mathrm{CC})$ (data not shown).

\section{TGF- $\beta-800$ SNP}

Four case-control studies on the association between TGF$\beta-800$ SNP and AD were identified. ${ }^{41,42,44,49}$ The effect of the TGF- $\beta-800$ genotype on the risk of AD is shown in the Table 1 . The effect of the AA genotype was to increase the $\mathrm{AD}$ risk in all the studies, but none of them showed a statistically significant difference. The pooled summary OR was 1.52 (AA vs. $\mathrm{AG}+\mathrm{GG}, \mathrm{OR}=1.52 ; 95 \% \mathrm{CI}, 0.86-2.96$ ), suggesting that subjects with the TGF- $\beta$ genotype -800 AA could have an higher risk of developing $\mathrm{AD}$, although it does not reach any statistical significance. Nor did we observe a statistically significant difference in disease risk when the GG genotype was compared with the other two aggregated genotypes $(\mathrm{AA}+\mathrm{AG})($ data not shown). There was no evidence of heterogeneity between the results of individual studies $\left(\chi^{2}=0.81, \mathrm{df}=3, p=0.85, I^{2}=0 \%\right)$.

This study summarizes the evidence to date regarding the association between common polymorphisms that comprehensively capture the variability of the TGF- $\beta$ gene and the risk of AD. The analysis of pooled data ruled out the role of TGF- $\beta$ SNPs in modifying AD risk that was hypothesized by some investigators. However, a remarkable heterogeneity was observed between the results of individual studies, suggesting differences among the enrolled populations and a possible population-specific genetic effect of the TGF- $\beta$ SNPs. Alternatively, genetic or environmental factors may also play a contributing role and may explain differences between the result of individual studies. We could not explain heterogeneity by subgroup analysis, taking into account study and patients characteristics, because of the low number of available studies.

So these data do not seemingly support a role for TGF- $\beta$ SNPs in the pathophysiology of AD. However, inflammatory mediators do not act alone; they act within a complex network in which they are interacting reciprocally. ${ }^{51}$ Accordingly, we found combinations of alleles in eight inflammatory genes and APOE that distinguish AD risk groups. $^{52}$

These studies are relevant to $\mathrm{AD}$ treatment. The occurrence of a high-risk genetic profile linked to the presence of high-responder alleles of proinflammatory cytokines or of low-responder alleles of antiinflammatory cytokines might suggest the treatment with biologics, such as monoclonal antibodies directed versus the proinflammatory cytokines. Decreasing the level of systemic inflammation in AD patients might be a suitable chemopreventive treatment because microglia may be activated by systemic stimuli. ${ }^{5,53}$

In fact, a recently published small, open-label pilot study suggested that inhibition of the inflammatory cytokine TNF$\alpha$ employing the perispinal administration of etanercept produced sustained clinical improvement in a 6-month, open-label pilot study in patients with AD ranging from mild to severe. This approach uses therapeutic delivery of etanercept across the dura via the cerebrospinal venous system, a confluence of the venous plexuses of the spine and the brain, in which flow is bidirectional owing to the absence of venous valves. Continued open-label clinical experience with this new treatment modality, now for more than 2 years, suggests that weekly maintenance treatment with perispinal

Table 1. Random-Effects Meta-Analyses Using Genotypic Contrasts for $-509,+10,-800$ Transforming Growth Factor- $\beta$ Single-Nucleotide Polymorphisms

\begin{tabular}{|c|c|c|c|c|c|}
\hline$S N P$ & $\begin{array}{l}\text { Studies } \\
\text { (n) }\end{array}$ & Ethnicity & $\begin{array}{l}\text { Participants } \\
\text { (n) }\end{array}$ & $\begin{array}{l}\text { Genotypic summary } O R \\
\quad(95 \% \mathrm{CI}), \mathrm{p} \text { value }\end{array}$ & $\begin{array}{l}\text { Heterogeneity } \\
\text { p value, } \mathrm{I}^{2}\end{array}$ \\
\hline-509 & 6 & $\begin{array}{l}3 \text { Europe (France, The Netherlands, Spain) } \\
2 \text { United States } \\
1 \text { Asia (Japan) }\end{array}$ & 10,452 & $\begin{array}{l}\text { TT vs. CT }+C C: 1.00 \\
\quad(0.78-1.28), p=0.98\end{array}$ & $p=0.09 ; 46.9 \%$ \\
\hline+10 & 4 & $\begin{array}{l}2 \text { Europe (Italy, The Netherlands) } \\
1 \text { United States } \\
1 \text { Asia (Japan) }\end{array}$ & 7663 & $\begin{array}{l}\text { CC vs. CT + TT: } 0.98 \\
(0.61-1.57), p=0.92\end{array}$ & $p=0.02 ; 69.9 \%$ \\
\hline-800 & 4 & $\begin{array}{l}\text { Europe (Italy, The Netherlands, Spain) } \\
1 \text { United States }\end{array}$ & 9898 & $\begin{array}{l}\text { AA vs. AG+ GG: } 1.52 \\
(0.86-1.20), p=0.15\end{array}$ & $p=0.85 ; 0 \%$ \\
\hline
\end{tabular}

Di Bona et al., unpublished observations.

SNP, Single-nucleotide polymorphism; OR, odds ratio; CI, confidence interval. 
etanercept may have a sustained positive effect. In addition, rapid clinical improvement within minutes of dosing has been observed on a repeated basis in multiple patients. It is hypothesized that perispinal administration of etanercept may enable rapid delivery to the central nervous system (CNS) via the cerebrospinal venous system, resulting in improvement in synaptic mechanisms that have been dysregulated by excess TNF- $\alpha$. Although some benefit was observed, firm conclusions cannot be drawn at present from these small trials. Perispinal etanercept for AD merits further study in randomized clinical trials. ${ }^{54-56}$

\section{Immune Response and Immunotherapy}

Some evidence suggests the involvement of a systemic immune response in AD, although so far it is poorly characterized. However, changes in the distribution and reactivity of immune cells in the blood have been observed. Neuroinflammation induces the efflux of CNS proteins, such as $\mathrm{A} \beta$, or inflammatory mediators across the blood-brain barrier. This may cause systemic immune reaction and recruitment of myeloid or lymphocytic cells into the CNS. Thus, communication between the CNS and immune system in $\mathrm{AD}$ could influence both the lymphocyte distribution in the blood and the production of immune mediators. ${ }^{11}$ Actually peripheral blood mononuclear cells (PBMCs) from AD patients produce higher levels of some cytokines, such as IL$1 \beta$ and IL-6, compared to levels of PBMCs from control subjects. ${ }^{57}$ Moreover, an immune disregulation was recently documented as dramatic alterations on $\mathrm{CD}^{+}{ }^{+}$subsets in patients with mild AD. In particular, decreased percentages of naïve cells and an increase of memory cells, an increased number of $\mathrm{CD}^{+}$lymphocytes that lack the co-stimulatory molecule $\mathrm{CD} 28$, and a reduction of $\mathrm{CD} 44^{+} \mathrm{CD} 25^{\text {high }} \mathrm{T}$ regulatory cells have been observed. ${ }^{58}$

To investigate the systemic signs of immune processes in $\mathrm{AD}$, Pellicanò et al. (unpublished observations) have examined the distribution of lymphocyte blood subsets in AD patients, comparing the results to data obtained in healthy controls. A decrease of B lymphocytes in AD patients due to a decrease of exhausted memory cells has been observed. In addition, the expression of activation markers on PBMCs from $\mathrm{AD}$ patients activated in vitro by recombinant (r)A $\beta 42$, was increased respect to controls. Stimulation by $\mathrm{rA} \beta 42$ also induced the production of the proinflammatory and antiinflammatory cytokines, chemokines, and growth factors (Table 2). This kind of study, which supportsthe involvement of systemic immunity in AD patients, can provide the basis for the search of immune biomarkers in AD for monitoring the effectiveness of therapeutic interventions. ${ }^{10}$

In fact, immune-based therapies targeting $\mathrm{A} \beta$ have generated considerable interest as a possible mechanism for reducing $\mathrm{A} \beta$ in the brain. Current views see immunization with the $\mathrm{A} \beta$ peptide or the infusion of preformed antibody specific for human $\mathrm{A} \beta$ as possible therapeutic approaches to improve the cognitive status in AD patients. Animal models of $\mathrm{AD}$ have provided positive results from both approaches. Thus, an initial clinical trial using immunization with human $\mathrm{A} \beta$ in $\mathrm{AD}$ patients was started, but then was halted because of a high incidence of meningoencephalitis. Passive immunotherapy in animal models of AD has provided similar benefits comparable to those seen with active immunother-
Table 2. Cytokines, Chemokines, and Growth Factors

Whose Secretion by Alzheimer Disease Peripheral

Blood Mononuclear Cells Is Significantly

INCREASED WHEN STIMULATED WITH rA $\beta 42$ with Respect to Control Cultures

\begin{tabular}{lll}
\hline Cytokines & Chemokines & Growth factors \\
\hline IL-1 $\beta$ & Eotaxin & GM-CSF \\
IL-1ra & MIP-1 $\beta$ & G-CSF \\
IL-6 & RANTES & \\
IFN- $\gamma$ & & \\
TNF- $\alpha$ & & \\
IL-10 & & \\
IL-8 & &
\end{tabular}

Cells were cultured in 24-well flat-bottomed plates at $1.5 \times 10^{6}$ cells per well in RPMI medium. The PBMCs were either unstimulated or stimulated by oligomeric $\mathrm{rA} \beta 42(10 \mu \mathrm{g} / \mathrm{mL})$. The supernatants of the cultured PBMCs were collected and the following cytokines and chemokines were evaluated using Luminex 100 (BioRad) according to manufacturer's instructions (Pellicanò et al., unpublished observations).

IL-1, Interleukin- 1 ; IFN- $\gamma$, interferon- $\gamma$; TNF- $\alpha$, tumor necrosis factor- $\alpha$; MIP- $1 \beta$, macrophage inflammatory protein- $1 \beta$; GM-CSF, granulocyte-macrophage colony-stimulating factor; G-CSF, granulocyte colony-stimulating factor.

apy, and in human beings it has the potential of being effective without inducing $\mathrm{T}$ cell-mediated encephalitis. ${ }^{59,60}$ Thus, intravenous immunoglobulin (IVIg) has been proposed as a potential agent for AD immunotherapy because it contains antibodies against $\mathrm{A} \beta$. In a recent study, administration of IVIg to patients with mild AD led to transient, reproducible, and dose-dependent increases in serum anti$\mathrm{A} \beta$ antibody titers and parallel increases in plasma $\mathrm{A} \beta$ levels. After 6 months of IVIg therapy, the cerebrospinal fluid (CSF) A $\beta$ levels decreased, whereas after 3 months without IVIg, a washout period, CSF $\mathrm{A} \beta$ levels increased to their pretreatment baseline levels. When IVIg therapy was restarted, a decrease in CSF A $\beta$ levels was again observed. In the meantime, a mean improvement of 2.5 points in Mini-Mental State Examination (MMSE) scores after 6 months was observed, with a decline of these scores toward baseline during the washout period. ${ }^{61}$

Furthermore, a retrospective case-control analysis demonstrated that previous treatment with IVIg is associated with a reduced risk of developing AD. Compared with untreated controls, patients who received previous IVIg for other indications had a $42 \%$ lower risk of developing AD over a period of approximately 4 years. This study provides epidemiologic evidence that previous IVIg may have a protective effect on the development of $\mathrm{AD} .^{62}$ It is well known that IVIg contains natural anti-A $\beta$ antibodies, and these natural antibodies have the capacity to prevent $\mathrm{A} \beta$ oligomerinduced neurotoxicity in N2A neuroblastoma cells. This neuroprotective effect may reflect the therapeutic potential of the natural anti-A $\beta$ antibodies found in IVIg for the treatment of patients with AD. ${ }^{63}$ It is also possible that other activities of IVIg, unrelated to its content of anti-A $\beta$ antibodies, such as the modulation of inflammatory and immune reactions, may complement the effects of anti-A $\beta$ antibodies on cognitive function in $\mathrm{AD}$ patients. The mechanisms of action of IVIg are complex, involving modulation of expression and function of Fc receptors, interference with 
activation of complement and the cytokine network and of idiotype network, regulation of cell growth, and effects on the activation, differentiation, and effector functions of dendritic cells and T and B cells. ${ }^{64}$ These promising preliminary findings encourage additional research involving both adequate, well-controlled, randomized clinical trials to evaluate the effects of IVIg more thoroughly in AD and well-designed studies that gain insight to immune response in $\mathrm{AD}$ patients.

\section{APOE, Cholesterol, and Diet}

The APOE4 allele is the only known genetic variant that has been clearly associated with increased risk of late-onset $\mathrm{AD}$. In the human population, three variants of the APOE gene have been found- $\varepsilon 2, \varepsilon 3$, and $\varepsilon 4$-that are able to influence the concentration of the lipoprotein in the bloodstream. The APOE proteins are associated with $10 \%$ of the difference in cholesterol concentration in the bloodstream whereas the allele $\varepsilon 4$ is tightly associated with the highest concentration. It has been demonstrated that subjects carrying APOE4 allele have a nearly double chance of developing $\mathrm{AD}$ whereas individuals not carrying the APOE4 allele have a decreased risk of AD by $40 \%$. Yet fewer than half of all AD patients possess the $\varepsilon 4$ allele and not all $\varepsilon 4$ carriers develop the disease. It has also been suggested that the main effect of the allele is to anticipate the onset of the disease. $4,65,66$

Although there have been numerous studies attempting to elucidate the underlying mechanism accounting for increased risk, the influence of APOE4 on AD onset and progression needs more convincing and critical evidence. However, prevailing indications suggest that the differential effects of APOE isoforms on $\mathrm{A} \beta$ aggregation and clearance play the major role in $\mathrm{AD}$ pathogenesis. Actually, the $\varepsilon 4$ allele accelerates amyloid deposition and promotes $\mathrm{A} \beta$ aggregation in cholesterol-rich lipid rafts, enhancing aggregation into senile plaques. In addition to its role in $\mathrm{A} \beta$ aggregation, it has been well argued that APOE4 promotes inflammatory responses. Other potential mechanisms, such as the differential modulation of neurotoxicity and tau phosphorylation by APOE4 isoforms, as well as its role in synaptic plasticity, have not been ruled out. ${ }^{4,67-69}$

On the other hand, the association between APOE, cholesterol, and AD has been the subject of intense scrutiny by numerous groups. High cholesterol levels at midlife are a considerable risk factor for dementia/AD in most of longterm follow-up studies. Moreover, the power of dietary fats on AD development was observed in APOE4 subjects only. To get a glimpse of cholesterol expression on $\mathrm{AD}$, we have to consider that the brain is very rich in cholesterol that is actively turned over among neurons and glial cells via apolipoproteins and their receptors play an essential role in synaptic plasticity. In addition, different cholesterol synaptic distribution depends on different APOE alleles. The beststudied role of cholesterol in $\mathrm{AD}$ is in amyloid precursor protein (APP) processing and $\mathrm{A} \beta$ generation. Increased cholesterol leads to increased cleavage of APP and increased $\mathrm{A} \beta$ production, whereas reduction of cellular cholesterol decreases the $\gamma$-secretase activity, which is responsible for $\mathrm{A} \beta$ generation. $^{4,70,71}$

Epidemiological studies have suggested a possible protective effect for the cholesterol-lowering statin drugs that inhibit 3-hydroxy-3-methyl-glutaryl-coenzyme A reductase, the enzyme that catalyzes the rate-limiting step in cholesterol, in AD patients. Numerous studies have examined the role of statins in the prevention of dementia and treatment of established AD. As matter of fact, as a biological point of view, it seems feasible that statins could prevent dementia due to their role in cholesterol reduction and in antiinflammatory activities that are not directly dependent on lowering blood cholesterol. However, while evidence from retrospective case-control studies suggests a beneficial role of statins in the prevention of $\mathrm{AD}$, a similar benefit has not been established in prospective cohort studies or randomized clinical trials. ${ }^{4,72,73}$

On the other hand, cognitive impairment can be influenced by a number of other factors. The potential effect of nutrition has become a topic of increasing scientific and public interest. In particular, there are arguments that nutrients (food and/or supplements), such as vitamins, trace minerals, and lipids, can affect the risk of cognitive decline and dementia, especially in frail elderly people at risk of deficiencies. Unmistakably, aging is associated with cognitive dementia and $\mathrm{AD}$; concomitantly, aging is also associated with malnutrition and reduced intake of micro- and macronutrients. ${ }^{74}$ The role of diet in cognitive decline has not been looked into broadly, but because several dietary factors affect the risk of cardiovascular disease and some studies have suggested a link between cognitive decline and cardiovascular disease, ${ }^{75}$ diabetes mellitus, ${ }^{76}$ and hypertension, ${ }^{77}$ it might be assumed that dietary intake might also influence the risk of dementia.

High energy intake and increase in body mass index during middle age have been associated with defeat of cognitive function in old age, ${ }^{78}$ whereas low calorie intake was protective against $\mathrm{AD} .^{79}$ Nonetheless, the diet of $\mathrm{AD}$ patients seems to have deficiencies in omega-3 fatty acids, especially docosahexaenoic acid/eicosapentaenoic acid long-chain omega-3 fatty acids, and too few antioxidants. Unfortunately, there are only a few studies comparing diets of AD patients with age-matched controls, and they tend to show AD patients with lower amounts of omega-3 fatty acids, excess omega-6 fatty acids (which would also cause inflammation), too much sugar (insulin resistance and metabolic syndrome), and fewer antioxidants. ${ }^{80}$ Unfortunately, in the Rotterdam study, no correspondence was found between increased risk of dementia and dietary intake rich in saturated fatty acids, trans fatty acids, and cholesterol. ${ }^{81}$

On the other hand, there are studies showing a positive association between high intake of saturated and transunsaturated (hydrogenated) fats and increased risk of AD, because intake of polyunsaturated and monounsaturated fats seems to be protective against cognitive decline in the elderly. ${ }^{82,83}$ Overall the role of lipid in AD is difficult to pinpoint because the presence of the APOE4 allele seems to respond more efficiently to diet modulation, whereas the presence of APOE3 and APOE2 is less influenced by diet. ${ }^{84,85}$

Also homocysteine-related vitamins and antioxidant nutrients (vitamins E and C, carotenoids, flavonoids, enzymatic cofactors) seem to have a role in AD risk, and epidemiologic data suggest a protective role of the $\mathrm{B}$ vitamins, especially vitamins B9 and B12, regarding cognitive decline and dementia. ${ }^{86}$ Nonetheless other studies have shown conflicting results. ${ }^{87}$

Ambiguous results are evident also on the dietary fruit and vegetables supplementation. The Chicago Health and 
Aging Project has shown an association between cognitive decline with older age and high vegetable but not fruit consumption, ${ }^{88}$ whereas intervention studies on rats given a dietary supplement of fruit and vegetables extracts have shown a slowed age-related decline in neuronal and cognitive functions. ${ }^{89}$ However, the results on antioxidant nutrients may suggest the importance of having a balanced combination of several antioxidant nutrients to exert a significant effect on the prevention of cognitive decline and dementia, while taking into account the potential adverse effects of these nutrients. ${ }^{84}$

Higher adherence to a Mediterranean diet seems to be associated with borderline reduction in risk for developing mild cognitive impairment (MCI) and a reduction risk for conversion from $\mathrm{MCI}$ to $\mathrm{AD}^{26}$ whereas a Japanese diet seems to be less protective. ${ }^{90}$ The substantial difference consists in the intake of animal fat and complex carbohydrates, whereas a Japanese diet is poor in animal fat and rich in complex carbohydrates.

Overall, these studies take in account several among the known confounding factors and consider the impact of food habits, such as the regional cultures, social status, and educational level, together with the genetic effect. In conclusion, there are a great amount of large prospective studies demonstrating association with lower all-cause and cause-specific mortality; nevertheless, there is a need of further analysis to verify if those association can be a useful tools for preventing diseases.

\section{Oxidative Stress and Therapeutic Perspectives}

Oxidative stress is considered one of the most critical among the factors linked to AD pathophysiology. ${ }^{91}$ Actually, besides the pathological hallmarks of the disease, AD brains exhibit evidence of reactive oxygen species (ROS)-mediated injury, and free radical oxidative damage to key intracellular targets such as DNA or proteins has been shown to be a major cause of the neuronal cell death related to $\mathrm{AD} .^{92}$ Oxidative stress is the result of an unbalance between oxidant production and antioxidant defenses. The brain, compared to other organs, is more susceptible to oxidative stress for the following reasons: (1) High content of peroxidizable unsaturated fatty acids; (2) high oxygen consumption per unit weight; (3) high content of lipid peroxidation key ingredients (iron and ascorbate); and (4) the scarcity of antioxidant defenses systems. Under normal conditions, free radicals are produced from a number of sources, among which are enzymatic, mitochondrial, and redox metal ion-derived sources as well as inflammatory response. ${ }^{93}$ In AD, an overproduction of free radicals seems to be mostly related to mitochondrial dysfunctions, to the $\mathrm{A} \beta$ peptides themselves, and to the presence of unbound trace metal ions. Today, it is evident that the three sources are not independent from each other, and recent hypotheses predict that, in the early stages of the disease, $\mathrm{A} \beta$ peptide enters the mitochondria where it induces ROS generation and subsequent oxidative stress. $^{94}$

The mechanisms associated with $\mathrm{A} \beta$-mediated neurotoxicity are still partially unknown, but there is evidence suggesting that oxidative stress plays a key role. ${ }^{94,95}$ Several groups showed that among the 42 amino acids forming $\mathrm{A} \beta(1-42)$, the methionine located at position 35 is critical for
$\mathrm{A} \beta$-associated ROS production and neurotoxicity. ${ }^{96,97}$ Furthermore, activation of microglial nicotinamide adenine dinucleotide phosphate (NADPH) oxidase by $\mathrm{A} \beta$ oligomers, $\mathrm{A} \beta$ fibrils, and senile plaque is responsible for the production of both extracellular and intracellular ROS, with direct toxicity to neurons and sustained production of several proinflammatory and neurotoxic cytokines. ${ }^{98,99}$

On the other hand, irrespective of the source and mechanisms that lead to the generation of intracellular toxic oxidants, mammalian cells have developed highly refined inducible systems to counteract stressful conditions and to fight off oxidation. ${ }^{100}$ Activation of antioxidant pathways is particularly important for tissue with relatively weak antioxidant defenses, such as the brain. Increasing evidence points out that reduced cellular expression and activity of antioxidant proteins are fundamental triggers for AD. ${ }^{101}$ Aging, the major risk factor for $\mathrm{AD}$, leads to loss of the free radical scavenging ability by endogenous mechanisms. ${ }^{102}$

Cortical and hippocampal oxidative stress is a very early event in the pathophysiology of sporadic AD and correlates with the development of specific cognitive deficits. This regional distribution has been strictly related to the amyloid load, because the cerebellum showed low levels of $\mathrm{A} \beta$, no oxidative stress relative to controls, and essentially no neuronal loss. ${ }^{103,104}$

Among cellular antioxidant defenses, heat shock proteins have been regarded as cytoprotectants protecting the brain cells from oxidative damages encountered during the neurodegenerative diseases progression. Heme oxygenase-1 $(\mathrm{HO}-1)$ is a $32-\mathrm{kD}$ stress protein that catalyzes the degradation of heme to biliverdin. ${ }^{105}$ The HO- 1 gene is redox regulated, and its activation represents a protective system potentially active against brain oxidative injury. ${ }^{106}$ Its expression in AD patients brain is significantly increased, ${ }^{107}$ and the spatial distribution of HO-1 expression in diseased brain is essentially identical to that of pathological expression of tau. ${ }^{108} \mathrm{HO}-1$ immunoreactivity is greatly increased in neurons and astrocytes of the hippocampus and cerebral cortex of individuals with AD and colocalizes in senile plaques and neurofibrillary tangles. $\mathrm{HO}-1$ is thought to downregulate the production of tau protein, and recently HO-1 polymorphisms have been considered as a possible responsible for increased AD susceptibility. ${ }^{109}$ Deregulation of the $\mathrm{HO}$ system has been associated with the pathogenesis of $\mathrm{AD}^{110}$, multiple sclerosis, ${ }^{111}$ and brain aging. ${ }^{112}$ Many studies clearly demonstrate that activation of HO-1 in neurons is strongly protective against oxidative damage and cell death. ${ }^{113,114}$ In fact, the activation of HO-1 seems to represent an important defensive mechanism for neurons exposed to oxidative stress. Thus, modulation of $\mathrm{HO}-1$ should represent a potential pharmaceutical strategy for the treatment of neurodegenerative disorders. ${ }^{8}$

Because oxidative stress may be responsible for some aspects of AD neurodegeneration, and because to date most of the available treatments are merely symptomatic, extensive research has been aimed at reducing the effects of oxidative stress to prevent $\mathrm{AD}$ progression by using free radical scavengers. Thus, one therapeutic strategy is to delay AD onset long enough so as to slow the neuronal damage associated with $\mathrm{A} \beta$-induced oxidative stress, particularly $\mathrm{A} \beta$ induced lipid peroxidation. Brain-accessible antioxidants potentially may provide the means of implementing this 
therapeutic strategy of delaying the onset of AD, acting as neuroprotective agents. Spices and herbs often contain active phenolic substances endowed with potent antioxidative and chemopreventive properties, ${ }^{115}$ and recently a series of papers have focused on specific neuroprotective effects of some of those polyphenols derived from nutritional sources. ${ }^{116}$ Curcumin (1,7-bis[4-hydroxy-3-methoxyphenyl]-1,6-heptadiene-3,5-dione), a coloring agent and food additive commonly used in Indian culinary and traditional medical preparations from time immemorial, is extracted from the rhizome of Curcuma longa. ${ }^{117}$ It is a polyphenolic substance that has the potential to inhibit lipid peroxidation and to effectively intercept and neutralize ROS (superoxide, peroxyl, hydroxyl radicals) ${ }^{118,119}$ and nitric oxide (NO)-based free radicals (nitric oxide and peroxynitrite). ${ }^{120}$ It is generally assumed that the phenol moiety is responsible for antioxidant properties of any plant phenolic compound. Consequently, the free radical chemistry of curcumin (an $o$-methoxyphenol derivative) has focused on its phenol ring. The possible involvement of the $\beta$-diketone moiety in the antioxidant action of curcumin has been considered, ${ }^{121}$ and the $\mathrm{H}$-atom donation from the $\beta$-diketone moiety to a lipid alkyl or a lipid peroxyl radical has been reported as the potentially more important mechanism underlying its antioxidant action. ${ }^{122}$ Of particular interest is the ability of curcumin to inhibit cyclooxygenase enzymes ${ }^{123}$ and to reduce the activation of nuclear transcription factor NF-кB. ${ }^{124}$ Its antiinflammatory properties and cancer-preventive activities have been consistently reported using in vitro and in vivo models of tumor initiation and promotion. ${ }^{125}$

In addition to its ability to scavenge carcinogenic free radicals, ${ }^{126}$ curcumin also interferes with cell growth through inhibition of protein kinases. Although the exact mechanisms by which curcumin promotes these effects remains to be elucidated, the electrophilic properties of this yellow pigment appear to be an essential component underlying its pleiotropic biological activities. Curcumin contains two electrophilic $\alpha, \beta$-unsaturated carbonyl groups, which can react with nucleophiles such as glutathione. ${ }^{127}$ In addition, curcumin can increase the activity of $\gamma$-glutamyl-cysteinyl synthetase and other glutathione (GSH)-linked detoxifying enzymes. ${ }^{128}$ Low concentrations of curcumin potently induce $\mathrm{HO}-1$ expression and activity in vascular endothelial cells, in rat astrocytes, and in cultured hippocampal neurons. Preincubation $(12 \mathrm{~h})$ of cultured neurons with a low concentration of curcumin resulted in an enhanced cellular resistance to glucose oxidase-mediated oxidative damage. This cytoprotective effect was considerably attenuated by zinc protoporphyrin IX, a specific inhibitor of HO activity. ${ }^{129-131}$ In other experiments, it has been demonstrated the efficacy of curcumin to protect cortical neurons against apoptotic cell death induced by $\mathrm{A} \beta .^{132}$ The ability of curcumin to induce $\mathrm{HO}-1$ can explain, at least in part, the strong antioxidant and antiinflammatory properties of curcumin, which depend more by its action as cellular signals than by its radical scavenger effect. ${ }^{133}$

The involvement of curcumin in restoring cellular homeostasis and rebalancing redox equilibrium by the activation of defensive genes suggests that it might also be a useful adjunct in AD treatment. Neuroprotective effects of curcumin have been demonstrated by Rajakrishnan ${ }^{134}$ in ethanolinduced brain damage; oral administration of curcumin in rats caused a significant reversal in lipid peroxidation, brain lipid modifications, as well as increase in glutathione levels. Epidemiological studies have suggested that curcumin, as one of the most prevalent nutritional and medicinal compounds used by the Indian population, is responsible for the significantly reduced (4.4-fold) prevalence of AD in India compared to United States. ${ }^{135}$ Furthermore, elderly Singaporeans who ate curry with turmeric had higher MMSE scores than those who did not. ${ }^{136}$ However, the relatively short duration of follow up, cultural factors, and other potential confounders suggest caution in interpreting these findings. Consistent with these data, convincing evidence has been provided that dietary curcumin given to an $\mathrm{AD}$ transgenic mouse model (Tg2576) for 6 months resulted in a suppression of indices of inflammation and oxidative damage in the brain of these mice and reversed $\mathrm{A} \beta$-induced cognitive deficits. ${ }^{137,138}$ The same group demonstrated in a successive study that curcumin was a better A $\beta 40$ aggregation inhibitor than ibuprofen and naproxen and prevented A $\beta 42$ oligomer formation and toxicity at very low concentrations (between 0.1 and $1.0 \mu \mathrm{M}$ ). ${ }^{139}$ They also showed that curcumin readily entered the brain to label plaques in vivo, inhibiting the formation of $\mathrm{A} \beta$ oligomers and their toxicity. Among the several mechanisms by which curcumin is able to clear amyloid is the induction of heat shock proteins (HSPs), which function as molecular chaperones to block protein aggregate formation. ${ }^{140}$

Recently, curcumin has been evaluated, with preliminary encouraging results, in a pilot clinical trial in AD patients. ${ }^{141}$ Curcumin is highly lipophilic and might cross the bloodbrain barrier and reach the brain, and, although its bioavailability is very low, because the drug is rapidly metabolized by conjugation, curcumin may reach brain concentrations sufficient to activate signal transduction events and to decrease $\mathrm{A} \beta$ aggregation. ${ }^{142}$ Other plant-derived phenolic agents with analogous chemical structures to curcumin have been demonstrated to strongly activate HO-1 expression and to defend cells against oxidative stress-in particular carnosol, ${ }^{143}$ zerumbone $^{144}$ resveratrol, ${ }^{145}$ rosolic acid, ${ }^{146}$ and sulforaphanes. ${ }^{147}$ Furthermore it has been demonstrated that other phenolics, such as caffeic acid phenethyl ester (CAPE), ${ }^{130}$ ethyl ferulate (EFE), ${ }^{148}$ and epigallocatechin-3-gallate (EGCG), ${ }^{149}$ are able to protect neurons via HO-1 induction.

\section{Conclusions}

Today, many countries have rising aging populations and are facing an increased prevalence of age-related diseases, such as $\mathrm{AD}$, with growing health-care costs. Understanding the $\mathrm{AD}$ pathophysiology process plays a prominent role in developing new strategies that can extend the health of the elderly population. In fact, taking into account the future epidemic of $\mathrm{AD}$, prevention and treatment are important goals of ongoing research. As discussed in this review, events contributing to the onset and development of AD are numerous and complex. We have focused our attention on many hot topics involved in AD pathophysiology, such as inflammation, cytokines, immune response, APOE, cholesterol, and oxidative stress, and have explored the related therapeutic possibilities, i.e., NSAIDs, cytokine blockade, immunotherapy, diet, and curcumin. We believe that the investigation of AD pathophysiology, particularly 
disentangling inflammation, is likely to provide important clues about how to develop drugs that can slow or delay AD.

\section{Acknowledgments}

Laura Castiglia and Mariavaleria Pellicanò are Ph.D. students at the Pathobiology Ph.D. course (directed by Calogero Caruso) of Palermo University, and this work is submitted in partial fulfilment of the requirement for their Ph.D. degree.

\section{References}

1. Hebert LE, Scherr PA, Beckett LA, Albert MS, Pilgrim DM, Chown MJ, Funkenstein HH, Evans DA. Age-specific incidence of Alzheimer's disease in a community population. JAMA. 1995;273:1354-1359.

2. Wang XP, Ding HL. Alzheimer's disease: Epidemiology, genetics, and beyond. Neurosci Bull 2008;24:105-109.

3. Steinman L. Nuanced roles of cytokines in three major human brain disorders J Clin Invest. 2008;118:35573563.

4. Vasto S, Candore G, Listì F, Balistreri CR, Colonna-Romano G, Malavolta M, Lio D, Nuzzo D, Mocchegiani E, Di Bona $\mathrm{D}$, Caruso C. Inflammation, genes and zinc in Alzheimer's disease. Brain Res Rev 2008;58:96-105.

5. Vasto S, Candore G, Duro G, Lio D, Grimaldi MP, Caruso C. Alzheimer's disease and genetics of inflammation: a pharmacogenomic vision. Pharmacogenomics 2007; 8:1735-1745.

6. Eikelenboom P, Veerhuis R, Scheper W, Rozemuller AJ, van Gool WA, Hoozemans JJ. The significance of neuroinflammation in understanding Alzheimer's disease. J Neural Transm 2006;113:1685-1695.

7. Gasparini L, Racchi M, Binetti G, Trabucchi M, Solerte SB, Alkon D, Etcheberrigaray R, Gibson G, Blass J, Paoletti R, Govoni S. Peripheral markers in testing pathophysiological hypotheses and diagnosing Alzheimer's disease. FASEB J 1998;12:17-34.

8. Racchi M, Uberti D, Govoni S, Memo M, Lanni C, Vasto S, Candore G, Caruso C, Romeo L, Scapagnini G. Alzheimer's disease: New diagnostic and therapeutic tools. Immun Ageing 2008;5:7.

9. McNaull BB, Todd S, McGuinness B, Passmore AP. Inflammation and anti-inflammatory strategies for Alzheimer's disease. Gerontology 2010;56:3-14.

10. Scapagnini G, Caruso C, Vasto S, Pascale A, Romeo L, D'Agata V. Genetic risk factors and candidate biomarkers for Alzheimer's disease. Front Biosci 2010;1:616-622.

11. Britschgi M, Wyss-Coray T. Systemic and acquired immune responses in Alzheimer's disease. Int Rev Neurobiol. 2007;82:205-233.

12. McGeer EG, McGeer PL. The importance of inflammatory mechanisms in Alzheimer disease. Exp Geront 1998;33: 371-378.

13. Licastro F, Candore G, Lio D, Porcellini E, ColonnaRomano G, Franceschi G, Caruso C Innate immunity and inflammation in ageing: A key for understanding agerelated diseases. Immun Ageing 2005;2:8.

14. Wilson J T. Head injury and Alzheimer's disease. J Neurol Neurosurg Psychiatry 2003;74:857-862.

15. Smith J.D. Apolipoproteins and aging: Emerging mechanisms. Ageing Res. Rev 2002;1:345-365.

16. Sheng JG, Bora SH, Xu G, Borchelt DR, Price DL, Koliatsos VE. Lipopolysaccharide-induced-neuroinflammation increases intracellular accumulation of amyloid precursor protein and amyloid beta peptide in APPswe transgenic mice. Neurobiol Dis 2003;14:133-145.

17. Perry VH, Cunningham C, Holmes C. Systemic infections and inflammation affect chronic neurodegeneration. Nat Rev Immunol 2007;7:161-167.

18. Holmes C, El-Okl M, Williams A, Cunningham C, Wilcockson D and Perry V. Systemic infection, interleukin $1 \beta$, and cognitive decline in Alzheimer's disease. J Neurol Neurosurg Psychiatry 2003;74:788-789.

19. Armitage GC. Development of a classification system for periodontal diseases and conditions. Ann Periodontol 1999;4:1-6.

20. Kuo LC, Polson AM, Kang T. Associations between periodontal diseases and systemic diseases: A review of the inter-relationships and interactions with diabetes, respiratory diseases, cardiovascular diseases and osteoporosis. Public Health 2008;122:417-433.

21. Campisi G, Chiappelli M, De Martinis M, Franco V, Ginaldi L, Guiglia R, Licastro F, Lio D. Pathophysiology of agerelated diseases. Immun Ageing 2009;6:12.

22. Seymour GJ, Ford PJ, Cullinan MP, Leishman S, Yamazaki K. Relationship between periodontal infections and systemic disease. Clin Microbiol Infect 2007;13(Suppl 4): 3-10.

23. Riviere GR, Riviere KH, Smith KS. Molecular and immunological evidence of oral Treponema in the human brain and their association with Alzheimer's disease. Oral Microbiol Immunol 2002;17:113-118.

24. Romeo HE, Tio DL, Rahman SU, Chiappelli F, Taylor AN. The glossopharyngeal nerve as a novel pathway in immune-to-brain communication: Relevance to neuroimmune surveillance of the oral cavity. J Neuroimmunol 2001;115: 91-100.

25. Chalmers JM, Carter KD, Spencer AJ. Oral diseases and conditions in community-living older adults with and without dementia. Spec Care Dentist 2003;23:7-17.

26. Riley KP, Snowdon DA, Markesbery WR. Alzheimer's neurofibrillary pathology and the spectrum of cognitive function: findings from the Nun Study. Ann Neurol 2002; 51:567-577.

27. Stein PS, Desrosiers M, Donegan SJ, Yepes JF, Kryscio RJ. Tooth loss, dementia and neuropathology in the Nun Study. J Am Dent Assoc 2007;138:1314-1322.

28. in $\mathrm{t}^{\prime}$ Veld BA, Ruitenberg A, Hofman A, Launer LJ, van Duijn CM, Stijnen T, Breteler MM, Stricker BH. Nonsteroidal antiinflammatory drugs and the risk of Alzheimer's disease. N Engl J Med. 2001;345:1515-1521.

29. McGeer PL, Schulzer M, McGeer EG, Arthritis and antiinflammatory agents as possible protective factors for Alzheimer's disease: A review of 17 epidemiologic studies. Neurology 1996;47:425-432.

30. Breitner JC. NSAIDs and Alzheimer's disease: How far to generalise from trials? Lancet Neurol 2003;2:527.

31. Etminan M, Gill S, Samii A. Effect of non-steroidal antiinflammatory drugs on risk of Alzheimer's disease: Systematic review and meta-analysis of observational studies. BMJ 2003;327:128-133.

32. ADAPT Research Group, Martin BK, Szekely C, Brandt J, Piantadosi S, Breitner JC, Craft S, Evans D, Green R, Mullan M. Cognitive function over time in the Alzheimer's Disease Anti-inflammatory Prevention Trial (ADAPT): Results of a randomized, controlled trial of naproxen and celecoxib. Arch Neurol 2008;65:896-905. 
33. Bregman N, Karni A, Korczyn AD. Can treatment with nonsteroidal anti-inflammatory drugs protect from dementia? Arch Neurol 2009;66:539-540.

34. Vlad SC, Miller DR, Kowall NW, Felson DT. Protective effects of NSAIDs on the development of Alzheimer disease. Neurology 2008;70:1672-1677.

35. Akiyama H, Barger S, Barnum S, Bradt B, Bauer J, Cole GM, Cooper NR, Eikelenboom P, Emmerling M, Fiebich BL, Finch CE, Frautschy S, Griffin WS, Hampel H, Hull M, Landreth G, Lue L, Mrak R, Mackenzie IR, McGeer PL, O'Banion MK, Pachter J, Pasinetti G, Plata-Salaman C, Rogers J, Rydel R, Shen Y, Streit W, Strohmeyer R, Tooyoma I, Van Muiswinkel FL, Veerhuis R, Walker D, Webster S, Wegrzyniak B, Wenk G, Wyss-Coray T. Inflammation and Alzheimer's disease. Neurobiol Aging 2000; 21:383-421.

36. Griffin WS, Stanley LC, Ling C, White L, MacLeod V, Perrot LJ, White CL 3rd, Araoz C.Brain interleukin 1 and S100 immunoreactivity are elevated in Down syndrome and Alzheimer disease. Proc Natl Acad Sci USA 1989; 86: 7611-7615.

37. Di Bona D, Plaia A, Vasto S, Cavallone L, Lescai F, Franceschi C, Licastro F, Colonna-Romano G, Lio D, Candore G, Caruso C. Association between the interleukin-1beta polymorphisms and Alzheimer's disease: A systematic review and meta-analysis Brain Res Rev 2008;59:155-163.

38. Di Bona D, Candore G, Franceschi C, Licastro F, ColonnaRomano G, Cammà C, Lio D, Caruso C. Systematic review by meta-analyses on the possible role of TNF-alpha polymorphisms in association with Alzheimer's disease. Brain Res Rev 2009;61:60-68.

39. Wyss-Coray T, Lin C, Yan F, Yu GQ, Rohde M, McConlogue L, Masliah E, Mucke L. TGF-beta1 promotes microglial amyloid-beta clearance and reduces plaque burden in transgenic mice. Nat Med 2001;7:612-618.

40. Grainger DJ, Heathcote $\mathrm{K}$, Chiano M, Snieder H, Kemp PR, Metcalfe JC, Carter ND, Spector TD. Genetic control of the circulating concentration of transforming growth factor type beta1. Hum Mol Genet 1999;8:93-97.

41. Luedecking EK, DeKosky ST, Mehdi H, Ganguli M, Kamboh MI. Analysis of genetic polymorphisms in the transforming growth factor-beta1 gene and the risk of Alzheimer's disease. Hum Genet 2000;106:565-569.

42. Araria-Goumidi L, Lambert JC, Mann DM, Lendon C, Frigard B, Iwatsubo T, Cottel D, Amouyel P, ChartierHarlin MC. Association study of three polymorphisms of TGF-beta1 gene with Alzheimer's Disease. I Neurol Neurosurg Psychiatry 2002;73:62-64.

43. Arosio B, Bergamaschini L, Galimberti L, La Porta C, Zanetti M, Calabresi C, Scarpini E, Annoni G, Vergani C. $+10 \mathrm{~T} / \mathrm{C}$ polymorphisms in the gene of transforming growth factor-beta1 are associated with neurodegeneration and its clinical evolution. Mech Ageing Dev 2007;128: 553-557.

44. van Oijen M, Arp PP, de Jong FJ, Hofman A, Koudstaal PJ, Uitterlinden AG, Breteler MM. Polymorphisms in the interleukin 6 and transforming growth factor beta1 gene and risk of dementia. The Rotterdam Study. Neurosci Lett 2006;402:113-117.

45. McKhann G, Drachman D, Folstein M, Katzman R, Price D, Stadlan EM. Clinical diagnosis of Alzheimer's disease: Report of the NINCDS-ADRDA Work Group under the auspices of Department of Health and Human Services Task Force on Alzheimer's Disease. Neurology 1984; 34:939-944.
46. DerSimonian R, Laird N. Meta-analysis in clinical trials. Controlled Clin Trials 1986;7:177-188.

47. Nishimura M, Sakamoto T, Kaji R, Kawakami H. Influence of polymorphisms in the genes for cytokines and glutathione S-transferase omega on sporadic Alzheimer's disease. Neurosci Lett 2004;368:140-143.

48. Dickson MR, Perry RT, Wiener H, Go RC. Association studies of transforming growth factor-beta 1 and Alzheimer's disease. Am J Med Genet B Neuropsychiatr Genet 2005;139B:38-41.

49. Rodríguez-Rodríguez E, Sánchez-Juan P, Mateo I, Llorca J, Infante J, García-Gorostiaga I, Berciano J, Combarros O. Serum levels and genetic variation of TGF-beta1 are not associated with Alzheimer's disease. Acta Neurol Scand 2007;116:409-412.

50. Hamaguchi T, Okino S, Sodeyama N, Itoh $\mathrm{Y}$, Takahashi A, Otomo E, Matsushita M, Mizusawa H, Yamada M. Association of a polymorphism of the transforming growth factor-beta1 gene with cerebral amyloid angiopathy. J Neurol Neurosurg Psychiatry 2005; 76:696-699.

51. Vasto S, Candore G, Balistreri CR, Caruso M, ColonnaRomano G, Grimaldi MP Listi F, Nuzzo D, Lio D, Caruso C. Inflammatory networks in ageing, age-related diseases and longevity. Mech Ageing Dev 2007;128:83-91.

52. Licastro F, Porcellini E, Caruso C, Lio D, Corder EH. Genetic risk profiles for Alzheimer's disease: Integration of APOE genotype and variants that up-regulate inflammation. Neurobiol Aging 2007;28:1637-1643.

53. Perry $\mathrm{VH}$, The influence of systemic inflammation on inflammation in the brain: implications for chronic neurodegenerative disease. Brain Behav Immun 2004;18:407-413.

54. Tobinick E. Perispinal etanercept for treatment of Alzheimer's disease. Curr Alzheimer Res 2007;4:550-552.

55. Tobinick E. Perispinal etanercept for neuroinflammatory disorders. Drug Discov Today 2009;14:168-177.

56. Tobinick E. Tumour necrosis factor modulation for treatment of Alzheimer's disease: rationale and current evidence. CNS Drugs 2009;23:713-725.

57. Reale M, Iarlori C, Gambi F, Lucci I, Salvatore M, Gambi D. Acetylcholinesterase inhibitors effects on oncostatin- $M$, interleukin- 1 beta and interleukin- 6 release from lymphocytes of Alzheimer's disease patients. Exp Gerontol 2005;40: 165-171.

58. Larbi A, Pawelec G, Witkowski JM, Schipper HM, Derhovanessian E, Goldeck D, Fulop T. Dramatic shifts in circulating CD4 but not CD8 T cell subsets in mild Alzheimer's disease. J Alzheimers Dis 2009;17: 91-103.

59. Licastro F, Caruso C. Is immunotherapy an effective treatment for Alzheimer's disease? Immun Ageing 2004;1:3.

60. Weksler ME. The immunotherapy of Alzheimer's disease. Immun Ageing 2004;1:2

61. Relkin NR, Szabo P, Adamiak B, Burgut T, Monthe C, Lent RW, Younkin S, Younkin L, Schiff R, Weksler ME. 18Month study of intravenous immunoglobulin for treatment of mild Alzheimer disease. Neurobiol Aging 2009;30: 1728-1736.

62. Fillit H, Hess G, Hill J, Bonnet P, Toso C. IV immunoglobulin is associated with a reduced risk of Alzheimer disease and related disorders. Neurology 2009;73:180-185.

63. Szabo P, Relkin N, Weksler ME. Natural human antibodies to amyloid beta peptide. Autoimmun Rev 2008;7: 415-420.

64. Negi VS, Elluru S, Siberil S, Graff-Dubois S, Mouthon L, Kazatchkine MD, Lacroix-Desmazes S, Bayry J, Kaveri SV. 
Intravenous immunoglobulin: An update on the clinical use and mechanisms of action. I Clin Immunol 2007;27: 233-245.

65. Nussbaum RL and Ellis, CE. Genomic medicine: Alzheimer's disease and Parkinson's disease. N Engl J Med 2003;348:1356-1364.

66. Bird, TD, Genetic factors in Alzheimer's disease. N Engl J Med 2005;352:862-864.

67. Cordy M, Hooper NM, Turner AJ. The involvement of lipid rafts in Alzheimer's disease. Mol Membr Biol 2006;23: $111-122$.

68. Finch CE, Morgan TE. Systemic inflammation, infection, ApoE alleles, and Alzheimer's disease: A position paper. Curr Alzheimer Res 2007;4:185-189.

69. Kim J, Basak JM, Holtzman DM. The role of apolipoprotein E in Alzheimer's disease. Neuron 2009;63:287-303.

70. Kivipelto M, Solomon A. Cholesterol as a risk factor for Alzheimer's disease-epidemiological evidence. Acta Neurol Scand 2006;114:50-57.

71. de Chaves EP, Narayanaswami V. Apolipoprotein E and cholesterol in aging and disease in the brain. Future Lipidol 2008;3:505-530.

72. Kandiah N, Feldman HH. Therapeutic potential of statins in Alzheimer's disease. I Neurol Sci 2009;283:230-234.

73. McGuinness B, Craig D, Bullock R, Passmore P. Statins for the prevention of dementia. Cochrane Database Syst Rev 2009;15:CD003160.

74. Moreiras O, van Staveren WA, Amorim Cruz JA, Carbajal A, de Henauw S, Grunenberger F, Roszkowski W. Longitudinal changes in the intake of energy and macronutrients of elderly Europeans. SENECA Investigators. Eur J Clin Nutr 1996;50;S67-S76.

75. Breteler MM, Claus JJ, Grobbee DE, Hofman A. Cardiovascular disease and distribution of cognitive function in elderly people: The Rotterdam Study. BMJ 1994;308:1604.

76. Naor M, Steingrüber HJ, Westhoff K, Schottenfeld-Naor Y, Gries AF. Cognitive function in elderly non-insulindependent diabetic patients before and after inpatient treatment for metabolic control. J Diabetes Complications 1997;11:40-46.

77. Guo Z, Fratiglioni L, Winblad B, Viitanen M. Blood pressure and performance on the Mini-Mental State Examination in the very old. Cross-sectional and longitudinal data from the Kungsholmen Project. Am J Epidemiol 1997; 145:1106-1113.

78. Frisoni GB, Fratiglioni L, Fastbom J, Guo Z, Viitanen M, Winblad B. Mild cognitive impairment in the population and physical health: Data on 1,435 individuals aged 75 to 95. I Gerontol A Biol Sci Med Sci 2000;55:M322-M328.

79. Luchsinger JA, Tang MX, Shea S, Mayeux R. Caloric intake and the risk of Alzheimer disease. Arch Neurol 2002;59:1258-1263.

80. Engelhart MJ, Geerlings MI, Ruitenberg A, Van Swieten JC, Hofman A, Witteman JC, Breteler MM. Diet and risk of dementia: Does fat matter?: The Rotterdam Study. Neurology 2002;59:1915-1921.

81. Solfrizzi V, Colacicco AM, D'Introno A, Capurso C, Del Parigi A, Capurso SA, Argentieri G, Capurso A, Panza F. Dietary fatty acids intakes and rate of mild cognitive impairment. The Italian Longitudinal Study on Aging. Exp Gerontol 2006;41:619-627.

82. Solfrizzi V, Colacicco AM, D'Introno A, Capurso C, Torres F, Rizzo C, Capurso A, Panza Dietary intake of unsaturated fatty acids and age-related cognitive decline: A 8.5-year follow-up of the Italian Longitudinal Study on Aging. Neurobiol Aging 2006;27:1694-1704.

83. Del Parigi A, Panza F, Capurso C, Solfrizzi V. Nutritional factors, cognitive decline, and dementia. Brain Res Bull 2006;69:1-19.

84. Orsitto G, Seripa D, Panza F, Franceschi M, Cascavilla L, Placentino G, Paris F, Solfrizzi V, Dallapiccola B, Pilotto AJ. Apolipoprotein E genotypes in mild cognitive impairment subtypes. Am Geriatr Soc 2006;54:1965-1966.

85. Wengreen HJ, Munger RG, Corcoran CD, Zandi P, Hayden KM, Fotuhi M, Skoog I, Norton MC, Tschanz J, Breitner JC, Welsh-Bohmer KA. Antioxidant intake and cognitive function of elderly men and women: the Cache County Study. J Nutr Health Aging. 2007;11:230-237.

86. Morris MC, Evans DA, Schneider JA, Tangney CC, Bienias JL, Aggarwal NT. Dietary folate and vitamins B-12 and B-6 not associated with incident Alzheimer's disease. $\mathrm{J} \mathrm{Alz-}$ heimers Dis 2006;9:435-443.

87. Morris MC, Evans DA, Tangney CC, Bienias JL, Wilson RS. Associations of vegetable and fruit consumption with agerelated cognitive change. Neurology 2006;67:1370-1376.

88. Shukitt-Hale B, Cheng V, Joseph JA. Effects of blackberries on motor and cognitive function in aged rats. Nutr Neurosci 2009;12:135-140.

89. Scarmeas N, Stern Y, Mayeux R, Manly JJ, Schupf N, Luchsinger JA. Mediterranean diet and mild cognitive impairment. Arch Neurol 2009;66:216-225.

90. Ross GW, Petrovitch H, White LR, Masaki KH, Li CY, Curb JD, Yano K, Rodriguez BL, Foley DJ, Blanchette PL, Havlik R. Characterization of risk factors for vascular dementia: the Honolulu-Asia Aging Study. Neurology 1999;53: 337-343.

91. Markesbery WR. Oxidative stress hypothesis in Alzheimer's disease. Free Radic Biol Med 1997;23:134-147.

92. Butterfield DA, Stadtman ER. Protein oxidation processes in aging brain. Adv Cell Aging Gerontol 1997;2:161-191.

93. Halliwell B. Biochemistry of oxidative stress. Biochem Soc Trans 2007;35:1147-1150.

94. de la Monte SM, Wands JR. Molecular indices of oxidative stress and mitochondrial dysfunction occur early and often progress with severity of Alzheimer's disease. J Alzheimers Dis 2006;9:167-181.

95. Butterfield DA, Drake J, Pocernich C, Castegna A. Evidence of oxidative damage in Alzheimer's disease brain: Central role for amyloid beta-peptide. Trends Mol Med 2001;7: 548-554.

96. Clementi ME, Pezzotti M, Orsini F, Sampaolese B, Mezzogori D, Grassi C, Giardina B, Misiti F.Alzheimer's amyloid beta peptide (1-42) induces cell death in human neuroblastoma via bax $/ \mathrm{bcl}-2$ ratio increase: an intriguing role for methionine 35. Biochem Biophys Res Commun 2006;342: 206-213.

97. ButterWeld DA, Boyd-Kimball D. The critical role of methionine 35 in Alzheimer's amyloid beta-peptide (1-42)induced oxidative stress and neurotoxicity. Biochim Biophys Acta 2005;1703:149-156.

98. Wilkinson BL, Landreth GE. The microglial NADPH oxidase complex as a source of oxidative stress in Alzheimer's disease. J Neuroinflammation 2006;9;3:30.

99. Park L, Anrather J, Zhou P, Frys K, Pitstick R, Younkin S, Carlson GA, Iadecola C. NADPH-oxidase-derived reactive oxygen species mediate the cerebrovascular dysfunction induced by the amyloid beta peptide. J Neurosci 2005;25: 1769-1777. 
100. Calabrese V, Boyd-Kimball D, Scapagnini G, Butterfield DA. Nitric oxide and cellular stress response in brain aging and neurodegenerative disorders: The role of vitagenes. In Vivo 2004;18:245-267.

101. Calabrese V, Sultana R, Scapagnini G, Guagliano E, Sapienza $M$, Bella R. Nitrosative stress, cellular stress response, and thiol homeostasis in patients with Alzheimer's disease. Antioxid Redox Signal 2006;8;1975-1986.

102. Finkel T, Holbrook NJ.Oxidants, oxidative stress and the biology of aging. Nature 2000;408:239-247.

103. Hensley K, Hall N, Subramaniam R, Cole P, Harris M, Aksenov M, Aksenova M, Gabbita SP, Wu JF, Carney JM. Brain regional correspondence between Alzheimer's disease histopathology and biomarkers of protein oxidation. J Neurochem 1995;65:2146-2156.

104. Sultana R, Boyd-Kimball D, Poon HF, Cai J, Pierce WM, Klein JB, Merchant M, Markesbery WR, ButterWeld DA. Redox proteomics identiWcation of oxidized proteins in Alzheimer's disease hippocampus and cerebellum: An approach to understand pathological and biochemical alterations in AD. Neurobiol Aging 2006;27: 1564-1576.

105. Scapagnini G, D'Agata V, Calabrese V, Pascale A, Colombrita C, Alkon DL, Cavallaro S.Gene expression profiles of heme oxygenase isoforms in the rat brain Brain Res 2002;954:31-39.

106. Calabrese V, Signorile A, Cornelius C, Mancuso C, Scapagnini G, Ventimiglia B, Ragusa N, Dinkova-Kostova A. Practical approaches to investigate redox regulation of heat shock protein expression and intracellular glutathione redox state. Methods Enzymol 2008;441:83-110.

107. Premkumar DR, Smith MA, Richey PL, Petersen RB, Castellani R, Kutty RK. Induction of heme oxygenase-1 mRNA and protein in neocortex and cerebral vessels in Alzheimer's disease. J Neurochem 1996;65:1399-1402.

108. Takeda A, Perry G, Abraham NG, Dwyer BE, Kutty RK, Laitinen JT, Petersen RB, Smith MA. Overexpression of heme oxygenase in neuronal cells, the possible interaction with Tau. J Biol Chem 2000;275:5395-5399.

109. Mateo I, Sánchez-Juan P, Rodríguez-Rodríguez E, Infante J, Vázquez-Higuera JL, García-Gorostiaga I, Berciano J, Combarros O. Synergistic effect of heme oxygenase-1 and tau genetic variants on Alzheimer's disease risk. Dement Geriatr Cogn Disord 2008;26:339.

110. Takahashi M, Dore S, Ferris C.D, Tomita T, Sawa A, Wolosker H, Borchelt DR, Iwatsubo TS, Kim H, Thinakaran G, Sisodia SS, Snyder SH. Amyloid precursor proteins inhibit heme oxygenase activity and augment neurotoxicity in Alzheimer's disease. Neuron 2002;28:461-473.

111. Schipper HM. Heme oxygenase-1: Role in brain aging and neurodegeneration. Exp Gerontol 2000;35:821-830.

112. Colombrita C, Calabrese V, Stella AM, Mattei F, Alkon DL, Scapagnini G. Regional rat brain distribution of heme oxygenase- 1 and manganese superoxide dismutase mRNA: Relevance of redox homeostasis in the aging processes. Exp Biol Med 2003;228:517-524.

113. Chen K, Gunter K, Maines MD. Neurons overexpressing heme oxygenase- 1 resist oxidative stress-mediated cell death. J Neurochem 2000;75:304-312.

114. Le WD, Xie, WJ, Appel SH Protective role of heme oxygenase-1 in oxidative stress-induced neuronal injury. I Neurosci Res 1999;56:652-658.

115. Nakatani, N. Phenolic antioxidants from herbs and spices. Biofactors 2000;13:141-146.
116. Gómez-Pinilla, F. Brain foods: The effects of nutrients on brain function. Nat Rev Neurosci 2008;9:568-578.

117. Ammon HPT, Wahl MA. Pharmacology of Curcuma Longa. Planta Med 1991;57:1-7.

118. Priyadarsini KI, Guha SN, Rao MN. Physico-chemical properties and antioxidant activities of methoxy phenols. Free Radic Biol Med1998;24:933-941.

119. Martin-Aragon S, Benedi JM, Villar AM. Modifications on antioxidant capacity and lipid peroxidation in mice under fraxetin treatment. J Pharm Pharmacol 1997;49:49-52.

120. Sreejayan A, Rao MN. Nitric oxide scavenging by curcuminoids. J Pharm Pharmacol 1997;49:105-107.

121. Masuda T, Hidaka K, Shinohara A, Maekawa T, Takeda Y, Yamaguchi $\mathrm{H}$. Chemical studies on antioxidant mechanism of curcuminoid: analysis of radical reaction products from curcumin. J Agric Food Chem 1999;47:71-77.

122. Jovanovic SV, Boone CW, Steenken S, Trinoga M, Kaskey RB. How curcumin works preferentially with soluble antioxidants. J Am Chem Soc 2001;123:3064-3068.

123. Ramos-Gomez M, Kwak MK, Dolan PM, Itoh K, Yamamoto M, Talalay P, Kensler TW. Sensitivity to carcinogenesis is increased and chemoprotective efficacy of enzyme inducers is lost in nrf2 transcription factor-deficient mice. Proc Natl Acad Sci USA 2001;98:3410-3415.

124. Singh S, Aggarwal BB. Activation of transcription factor $\mathrm{NF}-\mathrm{kB}$ is suppressed by curcumin (diferuloylmethane). J Biol Chem 1995;270:24995-25000.

125. Huang MT, Newmark HL, Frenkel K. Inhibitory effects of curcumin on tumorigenesis in mice. J Cell Biochem Suppl 1997;27:26-34.

126. Abe $Y$, Hashimoto S, Horie T. Curcumin inhibition of inflammatory cytokine production by human peripheral blood monocytes and alveolar macrophages. Pharmacol Res 1999;39:41-47.

127. Awasthi S, Pandya U, Singhal SS, Lin JT, Thiviyanathan V, Seifert WE, Jr Awasthi YC, Ansari GA. Curcuminglutathione interactions and the role of human glutathione S-transferase P1-1. Chem Biol Interact 2000;128:19-38.

128. Singhal SS, Awasthi S, Pandya U, Piper JT, Saini MK, Cheng JZ, Awasthi YC. The effect of curcumin on glutathione-linked enzymes in K562 human leukemia cells. Toxicol Lett 1999;109:87-95.

129. Motterlini R, Foresti R, Bassi R, Green CJ. Curcumin, an antioxidant and anti-inflammatory agent, induces heme oxygenase- 1 and protects endothelial cells against oxidative stress. Free Radic Biol Med 2000;28:1303-1312.

130. Scapagnini G, Foresti R, Calabrese V, Giuffrida Stella AM, Green CJ, Motterlini R. Caffeic acid phenethyl ester and curcumin: a novel class of heme oxygenase- 1 inducers. Mol Pharmacol 2002;61:554-561.

131. Scapagnini G, Colombrita C, Amadio M, D'Agata V, Arcelli E, Sapienza M, Calabrese V. Curcumin activates defensive genes and protects neurons against oxidative stress. Antioxid Redox Signal 2006;8:395-403.

132. Scapagnini G, Calabrese V, Motterlini R, Colombrita C, Alkon DL. Use of curcumin derivatives or CAPE in the manufacture of a medicament for the treatment of neuroprotective disorders. World Patent Number: WO 2004/ 075883 A1, Publication date: 2004-09-10.

133. Goel, A, Kunnumakkara AB, Aggarwal BB. Curcumin as "Curecumin": From kitchen to clinic. Biochem Pharmacol 2008;75:787-809.

134. Rajakrishnan V, Viswanathan $P$, Rajasekharan KN, Menon VP. Neuroprotective role of curcumin from curcuma longa 
on ethanolinduced brain damage. Phytother Res 1999; 13:571-574.

135. Chandra V, Pandav R, Dodge HH, Johnston JM, Belle SH, DeKosky ST. Incidence of Alzheimer's disease in a rural community in India: The Indo-US study. Neurology 2001; 57:985-989.

136. Ng TP, Chiam PC, Lee T, Chua HC, Lim L, Kua EH. Curry consumption and cognitive function in the elderly. Am J Epidemiol 2006;164:898-906.

137. Lim GP, Chu T, Yang F, Beech W, Frautschy SA, Cole GM. The curry spice curcumin reduces oxidative damage and amyloid pathology in an Alzheimer transgenic mouse. J Neurosci 2001;21:8370-8377.

138. Frautschy SA, Hu W, Miller SA, Kim P, Harris-White ME, Cole GM. Phenolic anti-inflammatory antioxidant reversal of $\mathrm{A} \beta$-induced cognitive deficits and neuropathology. Neurobiol Aging 2001;22:993-1005.

139. Yang F, Lim GP, Begum AN, Ubeda OJ, Simmons MR, Ambegaokar SS. Curcumin inhibits formation of amyloid beta oligomers and fibrils, binds plaques, and reduces amyloid in vivo. J Biol Chem 2005;280:5892-5901.

140. Cole GM, Teter B, Frautschy SA. Neuroprotective effects of curcumin. Adv Exp Med Biol 2007;595:197-212.

141. Baum L, Lam CW, Cheung SK, Kwok T, Lui V, Tsoh J, Lam L, Leung V, Hui E, Ng C, Woo J, Chiu HF, Goggins WB, Zee BC, Cheng KF, Fong CY, Wong A, Mok H, Chow MS, Ho PC, Ip SP, Ho CS, Yu XW, Lai CY, Chan MH, Szeto S, Chan IH, Mok V. Six-month randomized, placebocontrolled, double-blind, pilot clinical trial of curcumin in patients with Alzheimer disease. I Clin Psychopharmacol 2008;28:110-113.

142. Begum AN, Jones MR, Lim GP, Morihara T, Kim P, Heath DD, Rock CL, Pruitt MA, Yang F, Hudspeth B, Hu S, Faull KF, Teter B, Cole GM, Frautschy SA. Curcumin structurefunction, bioavailability, and efficacy in models of neuroinflammation and Alzheimer's disease. J Pharmacol Exp Ther 2008;326:196-208.

143. Martin, D, Rojo AI, Salinas M, Diaz R, Gallardo G, Alam J, De Galarreta CM, Cuadrado A. Regulation of heme oxygenase-1 expression through the phosphatidylinositol 3-kinase/Akt pathway and the Nrf2 transcription factor in response to the antioxidant phytochemical carnosol. J Biol Chem 2004;279:8919-8929.

144. Surh YJ, Kundu JK, Na HK. Nrf2 as a master redox switch in turning on the cellular signaling involved in the induction of cytoprotective genes by some chemopreventive phytochemicals. Planta Med 2008;74:1526-1539.

145. Zhuang H, Kim YS, Koehler RC, Dore S. Potential mechanism by which resveratrol, a red wine constituent, protects neurons. Ann NY Acad Sci 2003;993:276-286.

146. Foresti R, Hoque M, Monti D, Green CJ, Motterlini R. Differential activation of heme oxygenase- 1 by chalcones and rosolic acid in endothelial cells. J Pharmacol Exp Ther 2005;312:686-693.

147. Talalay P, Fahey JW, Healy ZR, Wehage SL, Benedict AL, Min C, Dinkova-Kostova AT. Sulforaphane mobilizes cellular defenses that protect skin against damage by UV radiation. Proc Natl Acad Sci USA 2007;104:17500-17005.

148. Scapagnini G, Butterfield DA, Colombrita C, Sultana R, Pascale A, Calabrese V. Ethyl ferulate, a lipophilic polyphenol, induces HO-1 and protects rat neurons against oxidative stress. Antioxid Redox Signal 2004;6:811-818.

149. Kweon M.H, Adhami VM, Lee JS, Mukhtarm H. Constitutive overexpression of Nrf2-dependent heme oxygenase-1 in A549 cells contributes to resistance to apoptosis induced by epigallocatechin 3-gallate. I Biol Chem 2006;281:33761-33772.

Address correspondence to: Dr. Sonya Vasto

Dipartimento di Biopatologia e Metodologie Biomediche

Università di Palermo

Corso Tukory 211 90134 Palermo Italy

E-mail: s.vasto@unipa.it 